Reseña

\section{Manuel Moreno Alonso. Ramón Carande. La Historia y yo. Pamplona, Urgoiti, 2020, 638 pp. ISBN: 978-8412103632.}

El progreso del estudio de la historia en España durante el siglo xx ha vivido varias épocas bien conocidas por los estudiosos y el público en general. Desde el mundo académico decimonónico, convulsionado con el Desastre del 98, y que vive una rápida época de cambios que terminan en la II República, hasta la historia oficial del largo franquismo y la nueva era abierta con la democracia restaurada en 1978. Es una compleja evolución que el historiador aquí biografiado, Ramón Carande y Thovar, protagoniza a través de su quehacer historiográfico académico. La obra cumbre de Carande, Carlos V y sus banqueros, por su novedad, planteamiento, estilo e impacto posterior, es sin duda el motor que conduce este libro a su destino final, pues la biografía termina con la jubilación del autor en 1957, año en el que se publicaron los dos primeros tomos de esta. Su importancia, ya glosada por algunos historiadores de la economía, y la semblanza de su vida, ya emprendida por el mismo Carande y autores tan cercanos como uno de los hijos del biografiado, Bernardo Víctor, encuentran en el libro de Moreno Alonso una nueva interpretación gracias a dos virtudes. La primera es la amplia documentación recogida, que se basa fundamentalmente en el epistolario de Carande, así como en la documentación de varios archivos. Esta información encuentra un mayor alcance en el uso extensivo que el autor hace de la bibliografía existente no solo sobre la historia y los historiadores españoles del siglo xx, sino también sobre la vida cultural del país. Reivindicando el papel que en dicha vida tuvieron la historia y los historiadores en un mundo en el que literatos, periodistas, economistas, historiadores y académicos en general se encontraban y cruzaban frecuentemente, el autor ubica a Carande en la malla cultural de su tiempo, caracterizando además con precisión el ambiente académico de la primera mitad del siglo xx.

Esta última idea es una de las principales aportaciones de esta biografía, pues no se ocupa solo de Ramón Carande, sino que se dedica a entender al biografiado en las coordenadas culturales y académicas que presidieron su vida, de manera que cuando no existe constancia documental de algunas de sus opiniones o de su participación en asuntos con los que estaba relacionado, el autor reconstruye su entorno y plantea hipótesis que permiten, cuando menos, acercarnos a su mundo. Conocer la vida y obra de Ramón Carande pasa, por tanto, no solo por la aproximación a sus orígenes sociales y a su formación elemental, doctorado en Derecho en 1910, sino también a su trascendental adscripción a la Institución Libre de Enseñanza (ILE), su gravitación en torno a la Junta de Ampliación de Estudios (JAE) y a José Castillejo, y a su relación con los prohombres que condicionaban en buena medida la enseñanza y los puestos universitarios en materia de economía, como es el caso de Antonio Flores de Lemus, verda- dero factótum de la investigación en economía en las tres primeras décadas del siglo xx. A ello se suma la huella indeleble dejada por el krausismo en la ILE y la JAE, que le llevaron a completar su formación en la Alemania del II Reich desde 1911, pasando de forma breve por otros países europeos, de una manera más elemental en su juventud y de forma más sólida en un periodo posterior. Esta formación no le llevaría, sin embargo, a profundizar en la economía aplicada y el derecho de manera permanente en cuanto a su desempeño como investigador. Sí que estuvo dedicado a ambas materias como profesor universitario, primero en Murcia y luego en Sevilla, donde estuvo a cargo de la enseñanza de la Cátedra de Economía Política y Hacienda Pública. La ciudad de Sevilla y su ambiente intelectual dejarían huella en Carande, como primero lo hizo Madrid. En la Universidad de Sevilla llegaría a ocupar el cargo de rector. No obstante, desde muy pronto manifestaría su falta de entusiasmo por la enseñanza de las materias asociadas a la cátedra, y fue orientado precisamente por Flores de Lemus para dedicarse al estudio de la historia, que se reforzaría con su segunda estancia en Alemania en 1921. Fruto de una orientación más clara en su interés intelectual y de la segunda estancia alemana surgiría una de sus obras clásicas, Sevilla, fortaleza y mercado, publicado en 1925 y construido sobre los archivos sevillanos, y su participación en dos revistas claves en su vida: Anuario de Historia del Derecho Español y posteriormente Moneda y Crédito.

De esta manera comprendemos cómo Ramón Carande escaló puestos en el escalafón universitario y alcanzó prestigio en el mundo intelectual gracias a una personalidad abierta, en permanente relación con intelectuales y docentes pertenecientes a diversas tradiciones y materias, de uno u otro signo político, trabando sólidas amistades y abriendo un abanico de relaciones sociales en torno a las tertulias, actividades académicas y publicaciones. Se refleja aquí no solo la obra y pensamiento de Carande, sino también el mundo social e intelectual en el que ambas se definían, forjaban y plasmaban, siendo este uno de los principales aciertos de la obra. Queda al desnudo el funcionamiento del sistema universitario en los distintos momentos históricos de la España de la primera mitad de siglo, y el autor también realiza una crítica del poder de la ILE y de la escasa y mediocre producción en historia de la República, que merece ser tenida en consideración a la hora de reconstruir la evolución de la historiografía española. Se atiende también a la participación de Carande en asuntos políticos a través de su nombramiento para diversos cargos, como el de consejero de Estado o asesorías económicas durante la República y la dictadura franquista, su entrada en CAMPSA y la confianza depositada en él por la familia Urquijo, así como su participación en el banco como asesor. Se explica y recorre con nuevos aportes la vida de Carande en el Madrid republicano, la represión sufrida después de la guerra y su reintegración como profesor universitario, pasando por un proceso de depuración por el que tuvo que significarse política- 
mente y adoptar todos los signos externos de Falange y comportamientos que se exigían a los intelectuales y docentes del régimen de Franco, lo que produjo la incomprensión o tolerancia de aquellos intelectuales exiliados que lo conocieron. Precisamente la valoración de ese mundo, otrora cohesionado y después pulverizado por la guerra y el exilio en cuanto al cultivo de la historia y otras disciplinas se refiere, constituye otro acierto que da continuidad al fresco pintado sobre la historia universitaria anterior a 1936. El ascenso intelectual, político y universitario de Carande encuentra en el trauma de la guerra en el Madrid republicano y la depuración política una cesura que no supuso una desaparición conformista del biografiado, sino que hizo posible precisamente Carlos $V$ y sus banqueros, al permitirle reunir materiales en el Archivo General de Simancas y, sobre todo, disponer de tiempo para escribir los dos primeros tomos de esta magna obra, dotando a la historia económica de uno de sus clásicos imperecederos, el cual aún constituye una aportación muy importante a nuestra comprensión del mundo académico e intelectual del que somos herederos.

Manuel F. Fernández Chaves Universidad de Sevilla 